Dety Larasati, Bukman Lian, Diana Widhi Rachmawati/ Analisis Kesehatan Keuangan KUD Sumber Tani Mandiri Desa Sumber Harum Kabupaten Musi Banyuasin

\title{
ANALISIS KESEHATAN KEUANGAN KUD SUMBER TANI MANDIRI DESA SUMBER HARUM KABUPATEN MUSI BANYUASIN
}

\author{
Dety Larasati \\ Universitas PGRI \\ Bukman Lian \\ Universitas PGRI \\ Diana Widhi Rachmawati \\ Universitas PGRI \\ *dianawidhi72@gmail.com
}

\begin{abstract}
The formulation of the problem is What is the Health Level of Sumber Tani Mandiri KUD in Sumber Harum Village, Musi Banyuasin Regency in 2015-2018? The qualitative descriptive method used, the data collection technique using documentation techniques in the form of financial report data and questionnaires besides that it is used based on seven aspects, namely capital, productive asset quality, management, efficiency, liquidity, independence and growth, the identity of the cooperative. The results showed that the health level of KUD STM in 20152018 was in the fairly healthy category with an average of 75.85 with details (1) aspects of capital, healthy category; (2) quality aspects of earning assets in a healthy category; (3) management aspects in the supervision category; (4) management aspects in the supervision category; (5) the liquidity aspect is under a special supervision category; (6) independence and growth aspects in the special supervision category; (7) aspects of identity in the healthy category; (8) the health level of KUD STM for four years, namely in 2015-2018, the success score was 77.45; 75.4; 75.65; 74.9 and has a fairly healthy category.
\end{abstract}

Keywords: Cooperative Health Analysis

\section{PENDAHULUAN}

Negara Indonesia merupakan sebuah negara yang memiliki tiga badan usaha, pertama, Badan Usaha Milik Negara (BUMN), kedua, Badan Usaha Milik Swasta (BUMS), ketiga, Koperasi. Koperasi merupakan organisasi yang dilakukan oleh orang-orang atau kelompok yang memiliki kepentingan bersama dan menggunakan prinsip kekeluargaan.
Eksistensi koperasi dapat terlihat dalam pasal 33 Undang-Undang Dasar 1945: "Perekonomian disusun sebagai usaha bersama atas asas kekeluargaan". Melihat besarnya fungsi dan peran koperasi pada perekonomian Indonesia maka koperasi tersebut membutuhkan pembinaan dan pengawasan secara rutin dan berkelanjutan sebagai patokan untuk meningkatkan peran 
dan kualitas koperasi dalam perekonomian rakyat yang bekinerja sehat atau baik.

Untuk dapat meningkatkan

kesejahteraan bagi anggota serta menunjang usaha-usaha pemerintah yang adil dan makmur, koperasi merupakan lembaga yang cocok dikarenakan koperasi merupakan badan usaha yang bewatak sosial.Melihat bentuknya koperasi juga memiliki tujuan untuk mencari keuntungan atau yang sering disebut laba/ Sisa Hasil Usaha (SHU) yang dapat diperoleh dari keuntungan baik dari penjualan atau simpan pinjam yang dikurangi pengeluaran yang dapat berupa beban usaha.

Melihat pengertian diatas maka kondisi koperasi sangat penting sehingga koperasi di harapkan memiliki kondisi kesehatan yang baik dan terus menjaga kestabilannya terutama pada kondisi keuangan koperasi.Kesehatan dalam kondisi keuangan koperasi dapat terlihat dari mampu atau tidaknya koperasi dalam memenuhi hutang atau kewajiban jangka pendeknya.

Untuk melakukan penilaian koperasi pemerintah menerbitkan "Peraturan Pengawasan Kementerian Koperasi dan Usaha Kecil Menengah (UKM) Republik Indonesia Peraturan Nomor: 06 / Per / Dep / IV / 2016 Mengenai Penilaian Kesehatan Koperasi Simpan Pinjam dan Unit Simpan Pinjam, dalam peraturan ini tingkat kesehatan koperasi dapat dinilai menggunakan tujuh aspek yaitu; aspek permodalan, aspek kualitas aktiva produktif, aspek manajemen, aspek efesiensi, aspek likuiditas, aspek kemandirian dan pertumbuhan, dan aspek jati diri koperasi, dalam setiap aspek telah memiliki nilai atau bobot tersendiri, dan langkah selanjutnya mendapatkan skor atau nilai yang akan menentukan predikat kesehatan koperasi dari predikat sehat, cukup sehat, dalam pengawasan, dan dalam pengawasan khusus".

Untuk melakukan penilaian koperasi menggunakan data utama berupa laporan keuangan, dan laporan keuangan tersebut sudah memenuhi standar akuntansi keuangan yang disusun secara transparan dan dapat dimengerti oleh orang awam sehingga hasil dari penilaian tersebut merupakan hasil yang sebenarnya. Sehingga hasil dari penilaian tersebut dapat bermanfaat untuk anggota, calon anggota dan pengelola sebagai dasar atau gambaran pada saat akan mengambil keputusan.

Dalam melakukan penilaian koperasi, koperasi yang digunakan "merupakan sebuah Koperasi Unit Desa (KUD) Sumber Tani Mandiri (STM), KUD STM merupakan koperasi yang terletak di Desa Sumber Harum kecamatan Tungkal Jaya kabupaten Musi Banyuasin, wilayah kerja KUD STM sesuai dengan SK Badan Hukum No.0112/BH/VII/III, KUD STM ini didirikan pada tanggal 03 Juli 2006 dengan tujuan untuk bekerja sama dengan PT. Hindoli agar hasil panen kelapa sawit para petani di desa sumber harum dapat tersalurkan dengan baik, selain itu dengan adanya KUD STM ini petani tidak mengalami kesulitan dalam mendapatkan alat-alat pertanian dan juga simpan pinjam".

Berdasarkan latar belakang penelitian, maka rumusan masalah dalam penelitian ini adalah bagaimanatingkat Kesehatan keuangan KUD Sumber Tani Mandiri di Desa Sumber Harum Kabupaten Musi Banyuasin Tahun 2015-2018.Oleh karena itu tujuan dalam penelitian ini adalah untuk menganalisis tingkat kesehatan keuangan 
KUD Sumber Tani Mandiridi Desa Sumber Harum Kabupaten Musi Banyuasin Tahun 2015-2018. Fokus dan sub fokus penelitian ini adalah laporan keuangan tahun 2015-2018 KUD Sumber Tani Mandiri (KUD STM) yang berada di Desa Sumber Harum Kabupaten Musi Banyuasin.Hasil penelitian ini dapat memberi beberapa manfaat.Pertama, manfaat bagi koperasi yaitu diharapkan hasil dari penelitian ini dapat memberikan informasi dan pengetahuan tentang kondisi kesehatan KUD STM sekaligus sebagai acuan dalam pengambilan keputusan. Kedua, bagi peneliti yaitu sebagai rujukan bagi peneliti lanjutan lain yang akan melakukan penelitian tentang kesehatan koperasi.

\section{KAJIAN PUSTAKA DAN PENGEMBANGAN HIPOTESIS}

Rudianto (2010) "koperasi merupakan perkumpulan orang yang secara sukarela mempersatukan diri untuk berjuang meningkatkan kesejahteraan ekonomi mereka melalui pembentukan sebuah badan usaha yang dikelola secara demokratis". Rudianto (2010) "koperasi adalah badan usaha yang beranggotakan orang-orang atau badan hukum koperasi dengan melandaskan kegiatannya pada prinsip koperasi sekaligus sebagai gerakan ekonomi rakyat yang berdasarkan asas kekeluargaan”.

Afandi (2014) "yang dimaksud koperasi adalah badan hukum yang didirikan oleh orang perseorangan atau badan hukum koperasi, dengan pemisahan kekayaan para anggotanya sebagai modal untuk menjalankan usaha, yang memenuhi aspirasi dan kebutuhan ekonomi, sosial, dan budaya dengan nilai dan prinsip koperasi”. Rachmawati (2018) "koperasi adalah suatu perkumpulan beranggotakan orang-orang atau badan hukum, yang memberikan kebebasan kepada anggota untuk masuk dan keluar, dengan bekerjasama secara kekeluargaan menjalankan perusahaan untuk mempertinggi kesejahteraan jasmaniah para anggotanya".

Santosa (2018) "Koperasi Unit Desa (KUD) merupakan koperasi yang secara langsung berhubungan dengan usaha yang dilakukan oleh masyarakat desa".Menurut Aziz 1984 dalam Sosial dan Ekonomi Pertanian (2011) 'Koperasi Unit Desa (KUD) sebagai salah satu jenis koperasi yang paling terkenal dan yang paling banyak ditemukan di Indonesia terutama dalam dalam hal pelayanan berbagai kegiatan perekonomian di pedesaan untuk membina petani mempunyai fungsi penyaluran sarana produksi seperti pupuk, pestisida, bibit dan berbagai peralatan usaha tani, penyaluran barang keperluan sehari-hari dengan harga yang layak, menyediakan kredit dengan bungan yang rendah dan dengan syarat-syarat yang lunak, melakukan penyuluhan, pengelolaan dan pemasaran hasil serta bidang lain sesuai dengan keadaan koperasi yang bersangkutan”.

Harahap (2010) "laporan keuangan berarti menguraikan akun-akun laporan keuangan menjadi unit informasi dan melihat hubungannya yang bersifat signifikan dengan tujuan untuk mengetahui kondisi keuangan lebih dalam untuk menghasilkan keputusan yang tepat".Pada saat akhir tahun atau setiap akhir periode seorang akuntan atau bendahara harus membuat sebuah laporan keuangan koperasi untuk berbagai pihak yang membutuhkan baik pihak intern ataupun pihak ekstern. 
Achmadi (2014) "kesehatan adalah keadaan sejahtera dari badan, jiwa dan sosial yang memungkinkan setiap orang hidup produktif secara sosial dan ekonomis".Basuki (2012) "kesehatan adalah kesehatan yang meliputi kesehatan badan, rohani (mental) dan sosial, bukan hanya keadaan yang bebas penyakit, cacat dan kelemahan".Notoatmodjo (2010) "kesehatan secara awam merupakan keadaan seseorang dalam kondisi tidak sakit, tidak ada keluhan, dapat menjalankan kegiatan sehari-hari dan sebagainya.Sedangkan kesehatan dari aspek ekonomi terlihat dari seseorang (dewasa) itu produktif, dalam arti mempunyai kegiatan yang menghasilkan sesuatu yang dapat menyokong secara finansial terhadap hidupnya sendiri atau keluarganya".

Dalam melakukan penilaian kesehatan keuangan koperasi haruslah menggunakan penilaian yang sesuai dengan pedoman yang benar. Untuk melakukan penilaian menggunakan pedoman "Peraturan Menteri Negara dan UKM Republik Indonesia Nomor: 06/Per/Dep.6/IV/2016 tentang Perkoperasian Penilaian Koperasi Simpan Pinjam dan Usaha Simpan Pinjam”. Dalam peraturan ini terdapat beberapa aspek yang akan berpengaruh pada kondisi koperasi guna mengukur dan melihat kriteria tingkat kesehatan koperasi.

\section{METODE PENELITIAN}

Sedangkan "aspek yang dinilai antara lain aspek permodalan, aspek kualitas aktiva produktif, aspek manajemen, aspek efesiensi, aspek likuiditas, aspek pertumbuhan dan kemandirian, dan aspek jatidiri koperasi”" (Hodsay, 2019).

Tabel 1 Aspek Penilaian Tingkat Kesehatan Koperasi Simpan Pinjam dan Unit Simpan Pinjam

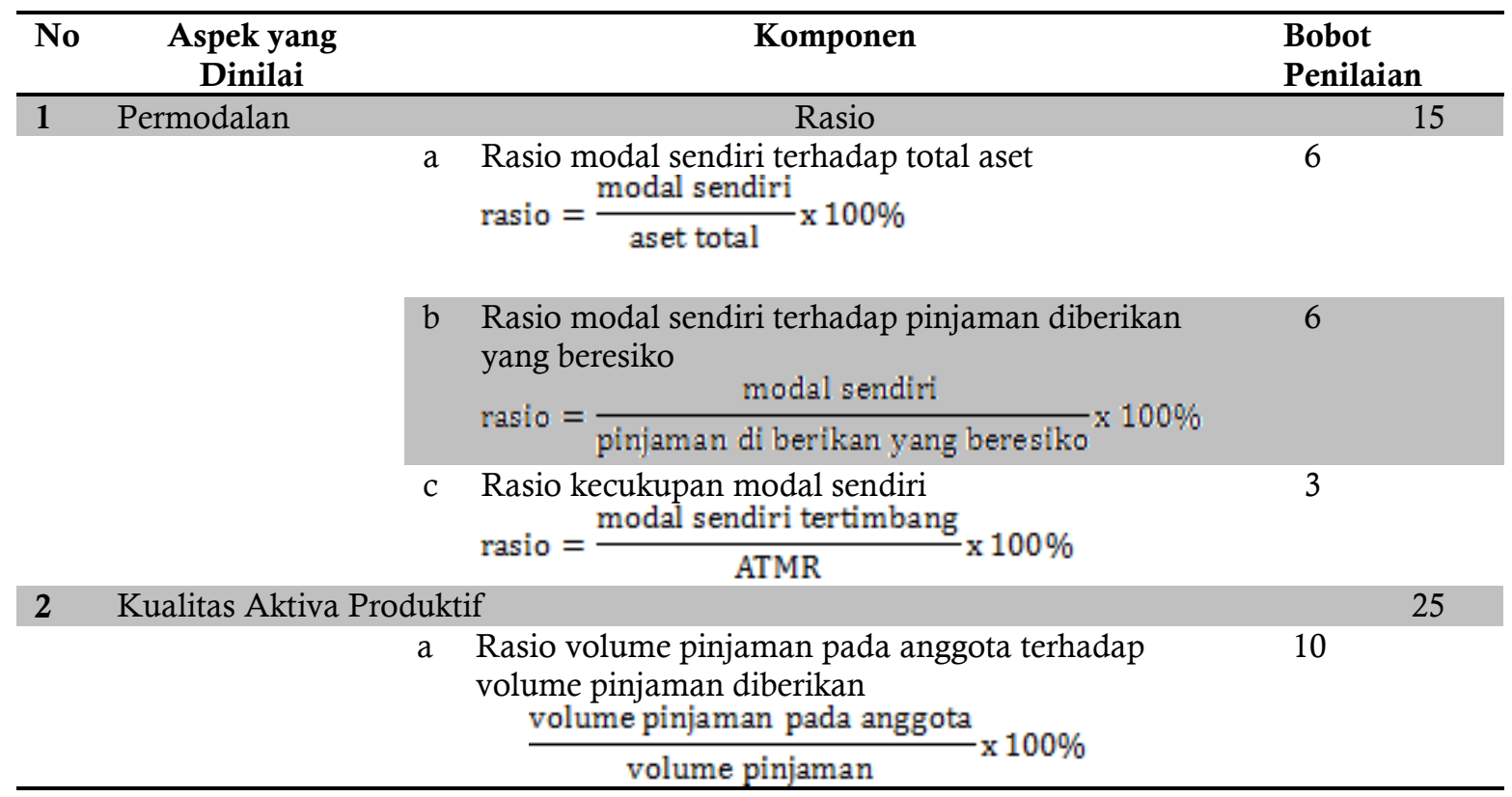




\begin{tabular}{|c|c|c|c|c|c|}
\hline & & $\mathrm{b}$ & $\begin{array}{l}\text { Rasio resiko pinjaman bermasalah terhadap pinjaman } \\
\text { yang diberikan } \\
\frac{\text { pinjaman bermasalah }}{\text { pinjaman yang diberikan }} \times 100 \%\end{array}$ & 5 & \\
\hline & & c & $\begin{array}{l}\text { Rasio cadangan risiko terhadap pinjaman berasalah } \\
\text { resiko cadangan } \\
\text { pinjaman bermaslah } \\
\text { Cat: cadangan resiko adalah cadangan tujuan } \\
\text { resiko + penyisihan penghapusan pinjaman }\end{array}$ & 5 & \\
\hline & & $\mathrm{d}$ & 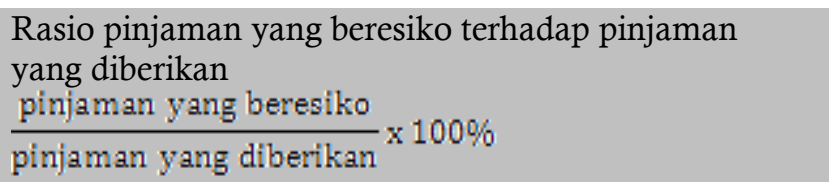 & 5 & \\
\hline \multirow[t]{6}{*}{3} & Manajemen & & & & 15 \\
\hline & & $\mathrm{a}$ & Manajemen umum & 3 & \\
\hline & & $\mathrm{b}$ & Kelembagaan & 3 & \\
\hline & & c & Manajemen permodalan & 3 & \\
\hline & & $\mathrm{d}$ & Manajemen aktiva & 3 & \\
\hline & & $\mathrm{e}$ & Manajemen likuiditas & 3 & \\
\hline \multirow[t]{4}{*}{4} & Efesiensi & & & & 10 \\
\hline & & $\mathrm{a}$ & $\begin{array}{l}\text { Rasio beban operasi terhadap partisipasi bruto } \\
\text { beban operasi amggota } \\
\text { partisipasi bruto } \\
\text { Cat: beban operasi anggota adalah beban pokok } \\
\text { ditambah denagan beban usaha bagi anggota }+ \\
\text { beban perkoperasian. Untuk USP koperasi, beban } \\
\text { perkoperasian dihitung secara proporsional. }\end{array}$ & 4 & \\
\hline & & $\mathrm{b}$ & $\begin{array}{l}\text { Rasio beban usaha terhadap SHU kotor } \\
\text { beban usaha } \\
\text { SHU kotor } \\
\times 100 \%\end{array}$ & 4 & \\
\hline & & c & $\begin{array}{l}\text { Rasio efisiensi pelayanan } \\
\text { biaya karyawam } \\
\text { wolume pinjaman }\end{array} 100 \%$ & 2 & \\
\hline \multirow[t]{3}{*}{5} & Likuiditas & & & & 15 \\
\hline & & $\mathrm{a}$ & $\begin{array}{l}\text { Rasio kas } \\
\quad \frac{\text { kas + bank }}{\text { kewajiban lancar }} \times 100 \%\end{array}$ & 10 & \\
\hline & & $\mathrm{b}$ & $\begin{array}{l}\text { Rasio pinjaman yang diberikan terhadap dana yang } \\
\text { diterima } \\
\text { pinjaman yang diberikan } \\
\text { dana yang diterima } \\
\text { Cat: dana yang diterima adalah total pasiva selain } \\
\text { hutang biaya dan SHU belum dibagi }\end{array}$ & 5 & \\
\hline \multirow[t]{2}{*}{6} & Kemandirian dan $\mathrm{Pc}$ & ertur & nbuhan & & 10 \\
\hline & & $\mathrm{a}$ & $\begin{array}{l}\text { Rasio rentabilitas aset } \\
\frac{\text { SHU sebelum pajak }}{\text { aset total }} \times 100 \%\end{array}$ & 3 & \\
\hline
\end{tabular}




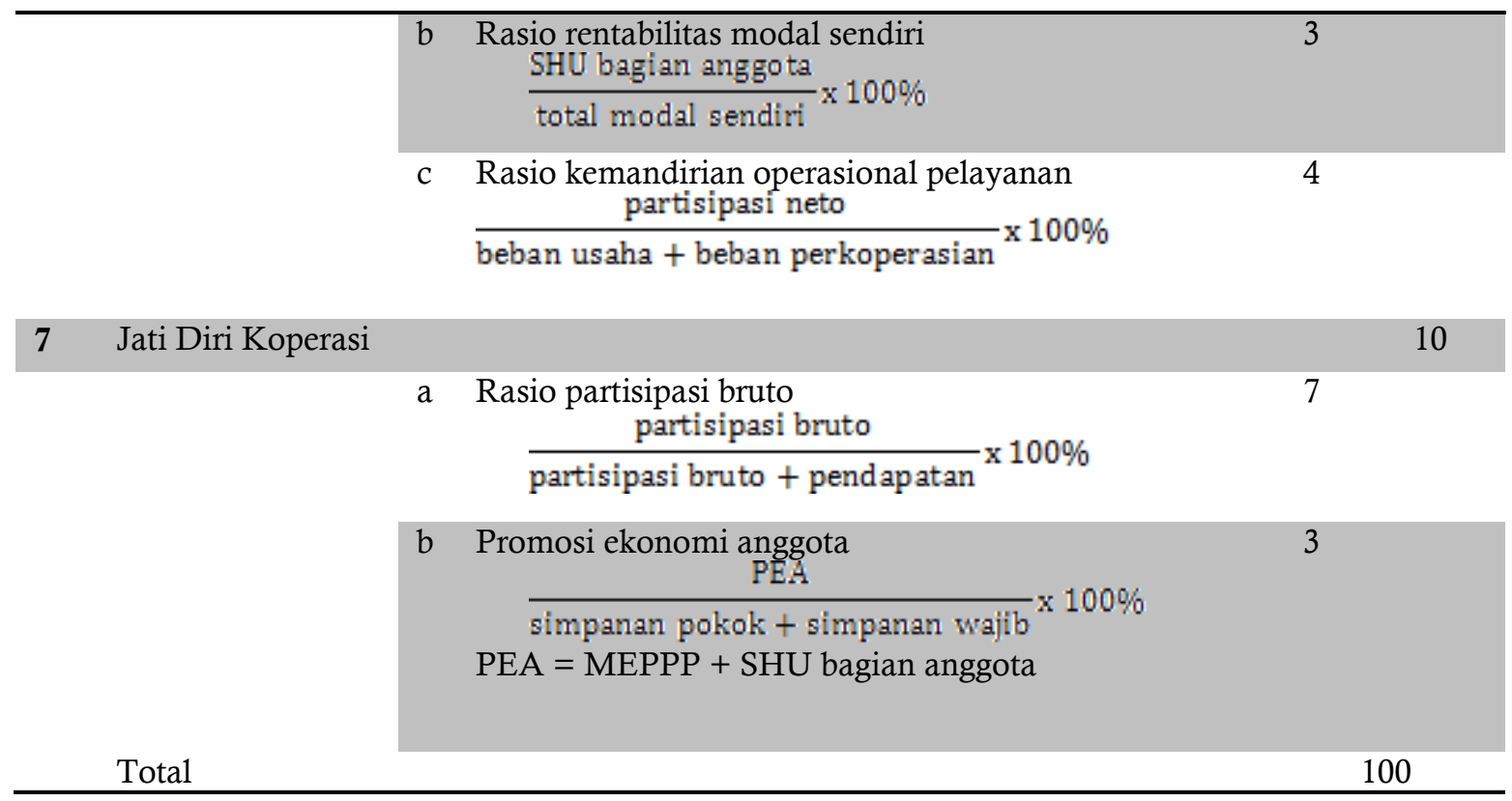

Sumber : Peraturan Menteri Negara Dan UKM Republik Indonesia Nomor: 06/Per/Dep.6/IV/2016

Objek penelitian ini merupakan laporan keuangan KUD STM pada tahun 2015-2018. Penelitian ini menggunakan data sekunder dan primer, untuk mendapatkan data maka peneliti meminta langsung pada informan penetiti yaitu ketua bendahara KUD STM. Teknik pengumpulan data yang digunakan merupakan teknik dokumentasi dan angket yang telah ditetapkan, dan metode yang digunakan dalam penelitian ini antara lain metode deskriptif kualitatif, dan teknik analisis data yang digunakan merupakan teknik yang berpedoman pada "Peraturan Menteri Negara dan UKM Republik Indonesia Nomor: 06/Per/Dep.6/IV/2016 tentang Perkoperasian Penilaian Koperasi Simpan Pinjam dan Usaha Simpan Pinjam”.

Setelah memperoleh hasil yang didapatkan dari perhitungan penilaian ketujuh aspek yang terdapat dalam peraturan tersebut maka selanjutnya adalah melihat tabel berikut untuk melihat kriteria atau kondisi kesehatan koperasi.

Tabel 2 Penetapan prediksi tingkat kesehatan KSP dan USP

\begin{tabular}{cc}
\hline Standar rasio & Kriteria \\
\hline $\mathbf{8 0 , 0 0} \leq \mathrm{x} \leq \mathbf{1 0 0}$ & Sehat \\
$\mathbf{6 6 , 0 0} \leq \mathrm{x} \leq \mathbf{8 0 , 0 0}$ & Cukup sehat \\
$\mathbf{5 1 , 0 0} \leq \mathrm{x} \leq \mathbf{6 6 , 0 0}$ & Dalam pengawasan \\
$<\mathbf{5 1 , 0 0}$ & Dalam pengawasan khusus \\
\hline
\end{tabular}

Sumber : Peraturan Menteri Negara Dan UKM Republik Indonesia Nomor:

06/Per/Dep.6/IV/2016

\section{HASIL DAN PEMBAHASAN}

Setelah melakukan perhitungan dengan menggunakan ketujuh aspek penilaian koperasi yang sesuai dengan pedoman "Peraturan Pengawasan Kementrian Koperasi 
dan Usaha Kecil Menengah (UKM) Republik Indonesia Peraturan Nomor: 06/Per/Dep.06/IV/2016 Mengenai Penilaian Kesehatan Koperasi Simpan Pinjam dan Unit Simpan Pinjam dan Rasio Likuiditas".
Dan dapat dilihat pada tabel dibawah ini merupakan hasil dari perhitungan dengan menggunakan ketujuh aspek tersebut.Selain itu dari tabel tersebut dapat dilihat bagaimana kondisi atau predikat KUD STM periode 2015-2018.

\section{Penilaian Aspek Permodalan KUD STM}

Tabel 3 Perhitungan hasil keseluruhan aspek permodalan tahun 2015-2018

Tabel 1. Contoh Penamaan Tabel

\begin{tabular}{cccccccccc}
\hline komponen & \multicolumn{8}{c}{ Hasil Perhitungan } \\
\cline { 2 - 9 } & 2015 & 2016 & Perbandingan & 2016 & 2017 & Perbandingan & 2017 & 2018 & Perbandingan \\
$\mathbf{1}$ & 6.00 & 6.00 & $\mathbf{0} \%$ & 6.00 & 6.00 & $\mathbf{0} \%$ & 6.00 & 6.00 & $\mathbf{0} \%$ \\
$\mathbf{2}$ & 6.00 & 6.00 & $\mathbf{0} \%$ & 6.00 & 6.00 & $\mathbf{0} \%$ & 6.00 & 6.00 & $\mathbf{0} \%$ \\
$\mathbf{3}$ & 3.00 & 2.25 & $\mathbf{- 3 7 . 5 \%}$ & 2.25 & 2.25 & $\mathbf{0} \%$ & 2.25 & 2.25 & $\mathbf{0} \%$ \\
Total & 15.00 & 14.25 & $\mathbf{- 3 7 . 5 \%}$ & 14,25 & 14,25 & $\mathbf{0} \%$ & 14,25 & 14,25 & $\mathbf{0} \%$ \\
\hline
\end{tabular}

Sumber : skor penilaian kesehatan KUD STM tahun 2015-2018

Dari tabel tersebut penulis dapat menyimpulkan bahwa KUD STM dilihat dari tabel tersebut memiliki kondisi atau predikat sehat dan memiliki skor yang stabil tetapi mengalami penurunan setelah tahun 2015 sebesar 37,5\% dapat dilihat pada tahun 2015 skor permodalan adalah 15,00 sedangkan pada tahun selanjutnya adalah 14,25. Hal tersebut terjadi dikarenakan adanya penurunan pada rasio kecukupan modal sendiri yang dikarenakan KUD STM pada tahun 2016 sudah tidak memiliki modal atau pinjaman dari pihak luar yang dikarenakan
KUD STM akan segera melakukan repalanting atau peremajaan kelapa sawit.

Dan dari perhitungan "aspek permodalan diKUD STM Tahun 2015 memperoleh skor 15,00 Tahun 2016 memperoleh skor 14,25 Tahun 2017 memperoleh skor 14,25 dan tahun 2018 memperoleh skor 14,25 dimana merurut Peraturan Pengawasan Kementerian Koperasi dan Usaha Kecil Menengah (UKM) Republik Indonesia Peraturan Nomor: 06/Per/Dep.06/IV/2016 skor maksimum aspek permodalan adalah 15 ".

\section{Penilaian Aspek Kualitas Aktiva Produktif KUD STM}

Tabel 4 Perhitungan hasil keseluruhan aspek kualitas aktiva produktif tahun 2015-2018

\begin{tabular}{cccccccccc}
\hline komponen & \multicolumn{8}{c}{ Hasil Perhitungan } \\
\cline { 2 - 10 } & 2015 & 2016 & Perbandingan & 2016 & 2017 & Perbandingan & 2017 & 2018 & Perbandingan \\
$\mathbf{1}$ & 10.00 & 10.00 & $\mathbf{0} \%$ & 10.00 & 10.00 & $\mathbf{0} \%$ & 10.00 & 10.00 & $\mathbf{0} \%$ \\
$\mathbf{2}$ & 5.00 & 5.00 & $\mathbf{0} \%$ & 5.00 & 5.00 & $\mathbf{0} \%$ & 5.00 & 5.00 & $\mathbf{0} \%$ \\
$\mathbf{3}$ & 5.00 & 5.00 & $\mathbf{0} \%$ & 5.00 & 5.00 & $\mathbf{0} \%$ & 5.00 & 5.00 & $\mathbf{0} \%$ \\
$\mathbf{4}$ & 5.00 & 5.00 & $\mathbf{0} \%$ & 5.00 & 5.00 & $\mathbf{0} \%$ & 5.00 & 5.00 & $\mathbf{0} \%$ \\
Total & 25.00 & 25.00 & $\mathbf{0} \%$ & 25.00 & 25.00 & $\mathbf{0} \%$ & 25.00 & 25.00 & $\mathbf{0} \%$ \\
\hline
\end{tabular}


Sumber : skor penilaian kesehatan KUD STM tahun 2015-2018

Dari tabel tersebut penulis dapat menyimpulkan bahwa kondisi atau tingkat kesehatan keuangan KUD STM menurut aspek kualitas aktiva produktif mendapatkan predikat sehat dan memiliki skor yang stabil, hal itu disebabkan karena KUD STM tidak memiliki pinjaman yang beresiko dalam volume pinjaman yang artinya uang yang dipinjam oleh anggota pasti akan kembali dikarenakan uang pinjaman tersebut akan langsung dipotong oleh KUD STM dari hasil penjualan kelapa sawit anggota, sehingga tidak akan menimbulkan pinjaman yang beresiko atau pinjaman yang bermasalah. Menurut hasil "perhitungan aspek kualitas aktiva produktif diKUD STM menunjukan bahwa pada Tahun 2015 memperoleh skor 25,00 Tahun 2016 memperoleh skor 25,00 Tahun 2017 memperoleh skor 25,00 dan tahun 2018 memperoleh skor 25,00, dimana merurut Peraturan Pengawasan Kementerian Koperasi dan Usaha Kecil Menengah (UKM) Republik Indonesia Peraturan Nomor: 06/Per/Dep.06/IV/2016 skor maksimum aspek kualitas aktiva produktif adalah 25 ”.

\section{Penilaian Aspek Manajemen KUD STM}

Tabel 5 Perhitungan hasil keseluruhan aspek kualitas aktiva produktif tahun 2015-2018

\begin{tabular}{cccccccccc}
\hline komponen & \multicolumn{7}{c}{ Hasil Perhitungan } \\
\cline { 2 - 10 } & 2015 & 2016 & Perbandingan & 2016 & 2017 & Perbandingan & 2017 & 2018 & Perbandingan \\
$\mathbf{1}$ & 3.00 & 3.00 & $\mathbf{0 \%}$ & 3.00 & 3.00 & $\mathbf{0} \%$ & 3.00 & 3.00 & $\mathbf{0} \%$ \\
$\mathbf{2}$ & 2.00 & 3.00 & $\mathbf{5 0} \%$ & 3.00 & 3.00 & $\mathbf{0} \%$ & 3.00 & 3.00 & $\mathbf{0} \%$ \\
$\mathbf{3}$ & 2.4 & 1.80 & $\mathbf{- 3 0 \%}$ & 1.80 & 1.80 & $\mathbf{0} \%$ & 1.80 & 1.80 & $\mathbf{0} \%$ \\
$\mathbf{4}$ & 1.5 & 0.60 & $\mathbf{- 4 5 \%}$ & 0.60 & 0.60 & $\mathbf{0} \%$ & 0.60 & 0.60 & $\mathbf{0} \%$ \\
$\mathbf{5}$ & 1.8 & 0.00 & $\mathbf{- 9 0 \%}$ & 0.00 & 0.00 & $\mathbf{0} \%$ & 0.00 & 0.00 & $\mathbf{0} \%$ \\
Total & 10.7 & 8.40 & $\mathbf{- 1 1 5 \%}$ & 8.40 & 8.40 & $\mathbf{0} \%$ & 8.40 & 8.40 & $\mathbf{0} \%$ \\
\hline
\end{tabular}

Sumber : skor penilaian kesehatan KUD STM tahun 2015-2018

Dari tabel berikut dapat disimpulkan bahwa aspek manajemen yang dimiliki oleh KUD STM mendapatkan predikat dalam pengawasan dengan skor yang cukupstabil tetapi mengalami penurunan pada tahun 2016 dapat dilihat pada tahun 2015 KUD STM memiliki skor 10,7 sedangkan tahun selanjutnya memiliki skor 8,40 hal tersebut terjadi karena pada tahun 2016 pada rasio manajemen permodalan KUD STM sudah tidak bisa mencukupi tingkat permodalan sendiri yang berasal dari anggota sebesar $10 \%$ dari tahun sebelumnya dan pertumbuhan modal yang tidak lebih besar dari aset. Dan pada rasio manajemen aktiva juga terjadi penurunan yang dikarenakan pada tahun 2016 pinjaman kolektibilitas lancar minimal $90 \%$ dari pinjaman yang diberikan sudah tidak tercukupi berbeda dengan tahun 2015. Dan pada rasio likuiditas juga mengalami penurunan yang dikarenkan KUD STM sudah tidak memiliki kebijakan tertulis serta informasi manajemen likuiditas tentang pengendalian likuiditas.Sehingga aspek manajemencukup mengalami penurunan secara drastis.

Dan hasil "perhitungan menunjukan bahwa aspek manajemen diKUD STM Tahun 
2015 memperoleh skor 10,7 dan mengalami penurunan pada Tahun 2016 yang memperoleh skor 8,4 Tahun 2017 memperoleh skor 8,4 dan tahun 2018 memperoleh skor 8,4 dimana merurut
Peraturan Pengawasan Kementerian Koperasi dan Usaha Kecil Menengah (UKM) Republik Indonesia Peraturan Nomor: 06/Per/Dep.06/IV/2016 skor maksimum aspek manajemen adalah 15 ".

\section{Penilaian Aspek Efesiensi KUD STM}

Tabel 6 Perhitungan hasil keseluruhan aspek efesiensi tahun 2015-2018

\begin{tabular}{cccccccccc}
\hline komponen & \multicolumn{8}{c}{ Hasil Perhitungan } \\
\cline { 2 - 9 } & 2015 & 2016 & Perbandingan & 2016 & 2017 & Perbandingan & 2017 & 2018 & Perbandingan \\
$\mathbf{1}$ & 3.00 & 4.00 & $\mathbf{5 0} \%$ & 4.00 & 4.00 & $\mathbf{0 \%}$ & 4.00 & 4.00 & $\mathbf{0} \%$ \\
$\mathbf{2}$ & 1.00 & 1.00 & $\mathbf{0 \%}$ & 1.00 & 1.00 & $\mathbf{0} \%$ & 1.00 & 1.00 & $\mathbf{0} \%$ \\
$\mathbf{3}$ & 1.50 & 0.00 & $\mathbf{- 7 5 \%}$ & 0.00 & 1.00 & $\mathbf{5 0} \%$ & 1.00 & 1.00 & $\mathbf{0} \%$ \\
Total & 5.50 & 5.00 & $\mathbf{- 2 5 \%}$ & 5.00 & 6.00 & $\mathbf{5 0} \%$ & 6.00 & 6.00 & $\mathbf{0} \%$ \\
\hline
\end{tabular}

Sumber : skor penilaian kesehatan KUD STM tahun 2015-2018

Dari tabel tersebut peneliti dapat menyimpulkan bahwa kesehatan KUD STM dilihat dari aspek efesiensi memiliki predikat dalam pengawasan dan terjadi penurunan pada tahun 2016 pada rasio efesiensi pelayanan yang dikarenakan terjadinya penurunan volume pinjaman pada biaya karyawan sehingga memperoleh persentasi 17,33\% dan mendapatkan skor 0,00. Dan pada tahun 2017 dan 2018 rasio efesiensi meningkat kembali sebesar 1.00 .
Dan menurut hasil "perhitungan aspek efesiensi menunjukan bahwa diKUD STM pada tahun 2015 memperoleh skor 5,50 Tahun 2016 memperoleh skor 5,00 Tahun 2017 memperoleh skor 6,00 dan tahun 2018 memperoleh skor 6,00 dengan skor rata-rata 5,6 dimana merurut Peraturan Pengawasan Kementerian Koperasi dan Usaha Kecil Menengah (UKM) Republik Indonesia Peraturan Nomor: 06/Per/Dep.06/IV/2016 skor maksimum aspek efesiensi adalah 10 ".

\section{Penilaian Aspek Likuiditas dan Rasio Likuiditas KUD STM}

Tabel 7 Perhitungan hasil keseluruhan aspek likuiditas tahun 2015-2018

\begin{tabular}{cccccccccc}
\hline komponen & \multicolumn{8}{c}{ Hasil Perhitungan } \\
\cline { 2 - 10 } & 2015 & 2016 & Perbandingan & 2016 & 2017 & Perbandingan & 2017 & 2018 & Perbandingan \\
$\mathbf{1}$ & 2.50 & 2.50 & $\mathbf{0 \%}$ & 2.50 & 2.50 & $\mathbf{0} \%$ & 2.50 & 2.50 & $\mathbf{0} \%$ \\
$\mathbf{2}$ & 5.00 & 5.00 & $\mathbf{0 \%}$ & 5.00 & 5.00 & $\mathbf{0} \%$ & 5.00 & 5.00 & $\mathbf{0} \%$ \\
\hline
\end{tabular}

Sumber : skor penilaian kesehatan KUD STM tahun 2015-2018

Dari tabel tersebut peneliti dapat menyimpulkan bahwa kesehatan KUD STM dilihat dari aspek likuiditas memiliki predikat dalam pengawasan khusus dan memiliki skor yang stabil, predikat dalam pengawasan khusus pada koperasi ini dikarenakan koperasi tidak membatasi jumlah nominal pada kas dan bank sehingga tidak sebanding 
dengan kewajiban lancar, karena jika skor persentasi rasio kas terlalu besar dan lebih dari $20 \%$ akan mendapatkan skor sebesar 2,5 . Dan menurut hasil "perhitungan aspek likuiditas ini dapat menunjukan bahwaKUD STM Tahun 2015 memperoleh skor 7,5 Tahun 2016 memperoleh skor 7,5 Tahun
2017 memperoleh skor 7,5 dan tahun 2018 memperoleh skor 7,5 dimana merurut Peraturan Pengawasan Kementerian Koperasi dan Usaha Kecil Menengah (UKM) Republik Indonesia Peraturan Nomor: 06/Per/Dep.06/IV/2016 skor maksimum aspek likuiditas adalah 15 ".

\section{Penilaian Aspek Kemandirian dan Pertumbuhan KUD STM}

Tabel 8 Perhitungan hasil keseluruhan aspek kemandirian dan pertumbuhan 2015-2018

\begin{tabular}{cccccccccc}
\hline komponen & \multicolumn{8}{c}{ Hasil Perhitungan } \\
\cline { 2 - 9 } & 2015 & 2016 & Perbandingan & 2016 & 2017 & Perbandingan & 2017 & 2018 & Perbandingan \\
$\mathbf{1}$ & 0,75 & 2.25 & $\mathbf{7 5 \%}$ & 2.25 & 1.50 & $\mathbf{- 3 7 . 5 \%}$ & 1.50 & 0.25 & $\mathbf{- 6 2 . 5 \%}$ \\
$\mathbf{2}$ & 3.00 & 3.00 & $\mathbf{0 \%}$ & 3.00 & 3.00 & $\mathbf{0} \%$ & 3.00 & 3.00 & $\mathbf{0} \%$ \\
$\mathbf{3}$ & 0.00 & 0.00 & $\mathbf{0 \%}$ & 0.00 & 0.00 & $\mathbf{0 \%}$ & 0.00 & 0.00 & $\mathbf{0 \%}$ \\
Total & 3.75 & 5.25 & $\mathbf{7 5 \%}$ & 5.25 & 4.50 & $\mathbf{- 3 7 . 5 \%}$ & 4.50 & 3.25 & $\mathbf{- 6 2 . 5 \%}$ \\
\hline
\end{tabular}

Sumber : skor penilaian kesehatan KUD STM tahun 2015-2018

Dari tabel tersebut peneliti dapat menyimpulkan bahwa kesehatan KUD STM dilihat dari aspek kemandirian dan pertumbuhan memiliki predikat dalam pengawasan khusus.Dapat dilihat dari tabel tersebut KUD STM pada tahun 2016 mengalami peningkatan sebesar $75 \%$ yang dikarenakan pada rasio rentabilitas aset memperoleh hasil $7,76 \%$ sehingga mendapatkan skor 2,25. Sedangkan pada tahun selanjutnya KUD STM mengalami penurunan pada rasio yang sama yaitu rasio rentabilitas aset yang dikarenakan hasil perbandingan antara SHU sebelum pajak pada total aktiva hanya mencapai $5,56 \%$ dan $4,90 \%$.

Dan dari hasil perhitungan tersebut menunjukan bahwa "aspek kemandirian dan pertumbuhan diKUD STM Tahun 2015 memperoleh skor 3,75 Tahun 2016 memperoleh skor 5,25 Tahun 2017 memperoleh skor 4,50 dan tahun 2018 memperoleh skor 3,25 dengan skor rata-rata 4,5 dimana merurut Peraturan Pengawasan Kementerian Koperasi dan Usaha Kecil Menengah (UKM) Republik Indonesia Peraturan Nomor: 06/Per/Dep.06/IV/2016 skor maksimum aspek kemandirian dan pertumbuhan adalah 10 ".

\section{Penilaian Aspek Jati Diri KUD STM}

Tabel 9 Perhitungan hasil keseluruhan aspek jati diri koperasi tahun 2015-2018

\begin{tabular}{cccccccccc}
\hline komponen & \multicolumn{10}{c}{ Hasil Perhitungan } \\
\cline { 2 - 10 } & 2015 & 2016 & Perbandingan & 2016 & 2017 & Perbandingan & 2017 & 2018 & Perbandingan \\
$\mathbf{1}$ & 7.00 & 7.00 & $\mathbf{0 \%}$ & 7.00 & 7.00 & $\mathbf{0 \%}$ & 7.00 & 7.00 & $\mathbf{0 \%}$ \\
$\mathbf{2}$ & 3.00 & 3.00 & $\mathbf{0 \%}$ & 3.00 & 3.00 & $\mathbf{0 \%}$ & 3.00 & 3.00 & $\mathbf{0} \%$ \\
\hline
\end{tabular}


Dety Larasati, Bukman Lian, Diana Widhi Rachmawati/ Analisis Kesehatan Keuangan KUD Sumber Tani Mandiri Desa Sumber Harum Kabupaten Musi Banyuasin

\begin{tabular}{cccccccccc}
\hline Total & 10.00 & 10.00 & $\mathbf{0 \%}$ & 10.00 & 10.00 & $\mathbf{0 \%}$ & 10.00 & 10.00 & $\mathbf{0 \%}$ \\
\hline
\end{tabular}

Sumber : skor penilaian kesehatan KUD STM tahun 2015-2018

Dari tabel tersebut peneliti dapat menyimpulkan bahwa kesehatan KUD STM dilihat dari aspek jati diri mendapatkan predikat sehatdengan skor yang stabil dan tidak mengalami penurunan dari hasil jatidiri itu dikarenakan pada rasio partisipasi bruto terdapat kontribusi anggota pada koperasi yang mencakup harga pokok dan partisipasi neto yang cukup besar sehingga dapat meningkatkan pendapatan koperasi. Dan pada rasio promosi anggota, walaupun KUD STM tidak memiliki promosi anggota yang besar tetapi SHU bagian anggota tetap sebanding dengan simpanan wajib dan simpanan pokok anggota sehingga mendapatkan skor yang tinggi pada aspek ini.

Dan menurut hasilnya menunjukan bahwa "aspek jati diri diKUD STM Tahun 2015 memperoleh 10,00 Tahun 2016 memperoleh skor 10,00 Tahun 2017 memperoleh skor 10,00 dan Tahun 2018 memperoleh skor 10,00 dimana merurut Peraturan Pengawasan Kementrian Koperasi dan Usaha Kecil Menengah (UKM) Republik Indonesia Peraturan Nomor: 06/Per/Dep.06/IV/2016 skor maksimum aspek jati diri koperasi adalah 10".

\section{Perkembangan Kesehatan KUD STM}

Tabel 10 Perhitungan hasil keseluruhan kesehatan KUD STM tahun 2015-2018

\begin{tabular}{cccccccccc}
\hline komponen & \multicolumn{10}{c}{ Hasil Perhitungan } \\
\cline { 2 - 10 } total & 2015 & 2016 & Perbandingan & 2016 & 2017 & Perbandingan & 2017 & 2018 & Perbandingan \\
\hline
\end{tabular}

Sumber : skor penilaian kesehatan KUD STM tahun 2015-2018

Dari penjelasan diatas telah menunjukan hasil perhitungan dan penilaian koperasi dengan menggunakan ketujuh aspek yang terdapat dalam "Peraturan Pengawasan Kementerian Koperasi dan Usaha Kecil Menengah (UKM) Republik Indonesia Peraturan Nomor: 06/Per/Dep.06/IV/2016" dari penjelasan tersebut maka peneliti dapat menyimpulkan bahwa KUD STM memiliki tingkat kesehatan cukup sehat tetapi pada tahun 2016 terjadi penurunan sebesar $102.5 \%$ hal itu terjadi karena pada aspek permodalan, manajemen dan efesiensi mengalami penurunan. Dan pada tahun 2017 mengalami kenaikan lagi sebesar $12.5 \%$ hal itu terjadi karena pada efesiensi yang tahun sebelumnya hanya 5.00 pada tahun 2017 menjadi 6.00 sehingga terjadi peningkatan walapun hanya sedikit. Selanjutnya pada tahun 2018 terjadi penurunan kembali hal ini disebabkan aspek pada aspek kemandirian dan pertumbuhan yang tahun sebelumnya memperoleh skor 4.50 menjadi 3.25.

Hal ini dapat dilihat bahwa "tingkat kesehatan KUD STM pada tahun 2015 memperoleh skor 77,46 dan mengalami penurunan pada tahun 2016 dengan memperoleh skor 75,4 selanjutnya pada tahun 2017 memeroleh skor 75,65 dan pada tahun 2018 memperoleh skor 74,9 penurunan ini 
diakibatkan terjadinya penurunan pada aspek kemandirian dan pertumbuhan pada bagian rasio rentabilitas aset yakni memperoleh skor 3,25, dari hasil tersebut dapat dilihat bahwa perolehan skor untuk menilai kesehatan KUD STM dari tahun 2015-2018 menunjukan tingkat kesehatan yang cenderung menurun dari tahun ketahun walaupun tidak terlihat secara signifikan, sedangkan berdasarkan hasil perhitungan rasio likuiditas secara umum KUD STM memiliki predikat dalam pengawasan khusus".

\section{KESIMPULAN}

Dilihat dari hasil penelitian dan perhitungan yang telah dijelaskan diatas maka "tingkat kesehatan KUD STM yang dilihat dari laporan keuangan yang terdiri dari laporan neraca dan laporan penghitungan hasil usaha tahun 2015-2018 dapat disimpulkan bahwa hasil penilaian kesehatan dari keseluruhan aspek KUD STM memiliki skor yaitu tahun 2015 sebesar 77,45 dengan ketegori cukup sehat, tahun 2016 sebesar 75,4 dengan ketegori cukup sehat, tahun 2017 sebesar 75,65 dengan kategori cukup sehat dan tahun 2018 sebesar 74,9 dengan ketegori cukup sehat, dari keseluruhan skor memiliki skor rata-rata 75,85 yang artinya KUD STM dalam kategori cukup sehat"

Dilihat dari kesimpulan yang telah diberikan peneliti di atas maka peneliti dapat memberikan saran berdasarkan hasil penelitian ini agar KUD STM dapat membangun dan meningkatkan tingkat kesehatan koperasi kedepannya dengan cara melakukan hal-hal sebagai berikut. Pertama, Bagi koperasi yaitu diharapkan koperasi dapat meningkatkan kualitas tingkat kesehatan dan menggunakannya sebagai alat dalam pengambilan keputusan. Kedua, Bagi penulis yaitu sebagai sebuah rujukan bagi peneliti lanjutan yang akan melakukan penelitian yang serupa yaitu tentang kesehatan koperasi.

\section{DAFTAR PUSTAKA}

Achmadi, U. F. (2014). Kesehatan Masyarakat Teori dan Aplikasi. Jakarta: PT Rajagrafindo Persada.

Afandi, P. (2014). Anailisis Kinerja Keuangan Untuk Mengukur Kesehatan Keuangan Koperasi KSU MBT Arafah Kecamatan Bancak Kabupaten Semarang. Among Makarti, Vol. 7 No. $13,25-47$.

Basuki, S. (2012). Kesehatan Olahraga. Solo: UNS Press.

Harahap, S. S. (2009). Analisis Kritis atas Laporan Keuangan. Jakarta: PT. Rajagrafindo Persada.

Hodsay, Z., \& Yolanda, Z. (2019). Analisis Penilaian Kesehatan Keuangan Koperasi Simpan Pinjam (KSP) Sejahtera SMK Muhammadiyah 2 Palembang. Jurnal Profit, Vol 6 Nomor 2, 114-125

Notoatmodjo, S. (2010). Promosi Kesehatan Teori dan Aplikasi. Jakarta: Rineka Cipta.

Peraturan Deputi Bidang Pengawasan Kementrian Koperasi dan Usaha Kecil dan Menengah Republik Indonesia Nomor: 06/Per/Dep.6/IV/2016 tentang pedoman penilaian kesehatan koperasi simpan pinjam dan unit simpan pinjam koperasi. 
Dety Larasati, Bukman Lian, Diana Widhi Rachmawati/ Analisis Kesehatan Keuangan KUD Sumber Tani Mandiri Desa Sumber Harum Kabupaten Musi Banyuasin

Rachmawati, D. W. (2018). Manajemen Pengelolaan Kinerja Keuangan Koperasi Sekolah SMK Swakarya Palembang. Jurnal Profit, Vol 5 No.2, 111-118.

Rudianto. (2010). Akuntansi Koperasi Edisi Kedua . Jakarta: Erlangga.

Santosa, D. S., \& Putri, I. Y. (2018). Peran Koperasi Unit Desa Dalam Kegiatan Usaha Masyarakat. FIRM Journal Of Manajement Studies, Vol 13 No. 2, 111.

Sibuea, M. B. (2011). Peranan Koperasi Unit Desa Dalam Meningkatkan Pendapatan Petani. Sosial dan Ekonomi Pertanian, Vol 8 No. 1, 1-12. 